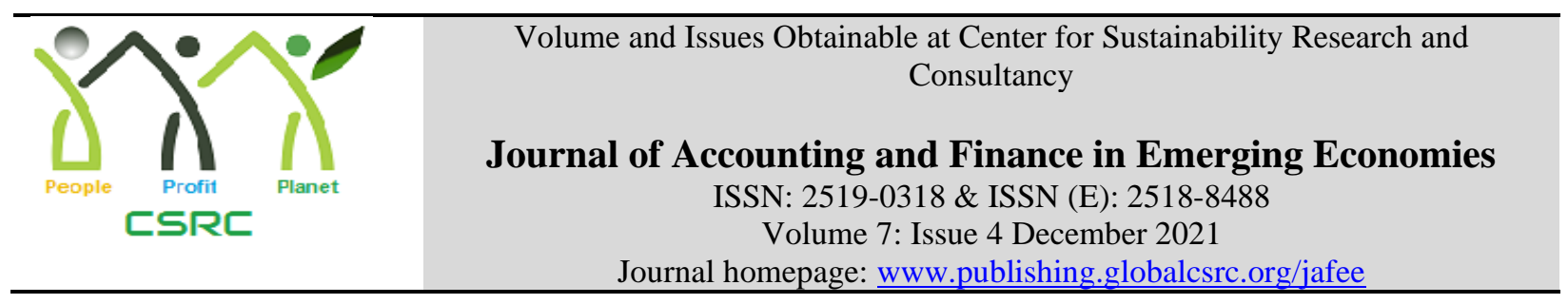

\title{
Business Incubators in Pakistan: State of the Art and Future Outlook
}

Sahar Hafeez, National University of Modern Languages, Islamabad, Pakistan

*Qamar Ali, Lyallpur Business School, Government College University Faisalabad, Pakistan

Muhammad Asim Nawaz, Lyallpur Business School, Government College University

Faisalabad, Pakistan

*Corresponding author's email: qamarali@gcuf.edu.pk

\begin{tabular}{l}
\hline ARTICLE DETAILS \\
\hline History \\
Revised format: Nov 2021 \\
Available Online: Dec 2021 \\
\hline Keywords \\
Business Incubation, SMEs, \\
Entrepreneurship, \\
Universities, Employment, \\
Pakistan \\
\hline JEL Classification \\
M1, M2
\end{tabular}

\section{ABSTRACT}

Purpose: In developing countries business incubators (BIs) have become a key catalyst for the flourishment of new ventures, due to overall weak financial health and opportunities for the startups. The purpose of this research is to evaluate the effectiveness of BIs in Pakistan and identify areas that need improvement. Design/Methodology/Approach: The study adopts a mixedmethod approach of social science research, using a cross-sectional survey of BI tenants in Pakistan $(n=100)$, triangulated with the help of in-depth interviews of key stakeholders of BIs $(n=12)$. Data from cross-sectional survey were analyzed using descriptive statistics and Paired Samples T-test methods. Data from interview responses were analyzed with the help of MAXQDA.

Findings: The study shows that the effectiveness of incubation facilities in Pakistan is less than the perceived importance and identifies which facilities tenants are most and least satisfied with. The findings of this study suggest that for BIs to be more effective in creating new ventures and providing employment opportunities, the Pakistani government must take concrete actions. New BI centers must be established to meet the market's demands and an evaluation process for existing BI centers must be implemented. To aid in the creation of new businesses in Pakistan, more university-based BIs should be established.

Implications/Originality/Value: The findings of this study are equally useful for the Government of Pakistan, BIs, and fresh startups.

(C) 2021, The authors, under a Creative Commons AttributionNonCommercial 4.0

Recommended citation: Hafeez, S., Ali, Q. A., and Nawaz, M. A. (2021). Business Incubators in Pakistan: State of the Art and Future Outlook. Journal of Accounting and Finance in Emerging Economies, 7 (4), 979-990.

\section{Introduction}

The economy of most developing countries is weak, and they are heavily reliant on borrowing money from other countries to meet their financial obligations. Pakistan is not an exception to this rule. Because of a lack of investment, Pakistan's economy has been in shambles for more than two 
decades. The country's financial situation necessitates the implementation of effective policies and actions pertaining to business activities and job creation (Shafi, Liu, \& Ren, 2020). Small and medium-sized enterprises (SMEs) are widely regarded as the backbone of a developing economy (Lu, Wu, Peng, \& Lu, 2020). In developing countries, on the other hand, the survival rate of new businesses is extremely low (Hyder \& Lussier, 2016). The majority of business ventures in troubled economies fail in their infancy or very early stages. A startup's most critical support is considered to be business incubation, which is especially important in developing countries that lack the necessary administrative and financial infrastructure to support businesses in their early stages (Shahzad, Bajwa, Ali, \& Zia, 2012).

Business incubators (BIs) serve as a safety net for start-up companies whose founders may not be able to afford the initial startup costs. To put it another way, when business owners are active and productive, they appreciate having BIs on their team. Business incubators provide a wide range of administrative and managerial services in order to create an environment that encourages the growth of new businesses. Because they are unable to afford these resources, the infants consider them to be luxurious. Businesses in the early stages of development strive to minimise the failure aspects of new ventures, such as a lack of information about the target market, an inability to withstand a massive capital loss, an inability to provide administrative services, management assistance, and so on (Yasin, Khansari, \& Tirmizi, 2021).

BIs (business incubators) are being investigated in Pakistan, and the purpose of this study is to determine their effectiveness. BIs provide facilities and appropriate support to new businesses in order to increase their chances of surviving (Hassan, 2020). As a result, the purpose of this study is to identify the most effective facilities that BIs in Pakistan provide to their tenants as well as to identify potential areas for future improvement. The findings of this study assist BIs in determining which services they are providing well and which services they need to improve on. It is hoped that the empirical evidence from this study will assist business incubators (BIs) and policymakers in Pakistan and other developing countries in developing and implementing more concrete initiatives to accelerate the incubation process and encourage more startups to register.

\section{Business Incubators: Definition and History}

There is no consensus among researchers on what constitutes business incubation. There are numerous descriptions of business incubation in the literature, but none of them are universally applicable (Hamdani, 2006). Business incubators (BIs) are organizations that provide a variety of essential resources to help start-ups and growing companies thrive, as well as organizations that are based locally to promote and assist new business ventures in their early stages, according to some definitions (Hackett \& Dilts, 2004). While other definitions of business incubators (BIs) emphasize the BIs' entrepreneurial qualities, the goal of establishing business incubators is to encourage entrepreneurship and, as a result, to aid in economic development. With this definition, business incubators have been unable to support technical entrepreneurs and the establishment of new businesses (Hackett \& Dilts, 2004).

Described by the United Kingdom Business Incubator (UKBI) as "a nurturing, instructive, and supportive environment for entrepreneurs during the critical stages of starting a new company," business incubation is "a nurturing, instructive, and supportive environment for entrepreneurs during the critical stages of starting a new company." An incubator's primary goal is to increase the likelihood of a startup's success while simultaneously shortening the time and lowering the cost of establishing and growing its business. "If successful, business incubators can assist in the development of companies that will serve as the true creators of a region's or nation's future wealth and employment opportunities" (Voisey et al., 2006, p21). In the United States and Europe, the origins of business interruptions can be traced back to the mid-twentieth century, during the rise of unemployment and the economic slump in the two countries. Beginning in the late 1970s and 
early 1980s, Western industrialized countries began establishing BIs to combat poverty (European Commission, Center for Strategy \& Evaluation Services, 2002).

Bhabra-Remedios and Cornelius (2003) examined the historical development of the concept of business incubation and asserted that it was first established in Batavia, Illinois, in 1959, according to their research. This concept was developed through collaboration between governments in Europe and the United States, as well as academic institutions. Growth was slow during the 1980s, despite the increased attention and expectations of the government at the time. Within two decades, the number of incubation centers and the businesses that they supported continued to grow at a steady pace. The public's understanding of the importance of a business incubation center has grown significantly, as has the significance of such a center. Historically, it is believed that the roots of incubation centres can be traced back to the development of managed workstations and creativity centres in the United Kingdom during the 1970s and 1980s (Atherton \& Hannon, 2006). (2006); (Atherton \& Hannon, 2006; There were 12 incubators in the United States in 1980; by 1984, the number had increased to approximately 20 per year, and by 1987, the number had increased to approximately 70.

A robust real estate factor, proximity to research institutes or technical university environments (e.g., industrial complexes), and proximity to research institutes or technical university environments (e.g., industrial complexes) are all characteristics of first generation incubators. Science, knowledge parks, and techno poles are examples of first generation incubators (Bruneel, Ratinho, Clarysse, \& Groen, 2012). Because of the significant public investments made in their real estate components over time, they are sometimes bolstered by national or local programmes for invention, job creation, and financial development. It is referred to as the "second generation" of incubators when simulated incubators are used. SMEs in fields with insufficient acute physique are likely to benefit from non-property-based projects, which require lower fixed investments and are seen as a viable option for providing services to them. University or research centres frequently house these incubators, which are distinguished by their ability to function both inside and outside the walls of the building. Working as "incubators without walls," they assist new ventures in getting off the ground without requiring them to remain in the incubator's facilities for an extended period of time.

International business incubators are considered to be of the "third generation." They provide a comprehensive set of support services to help knowledge-based businesses grow and succeed in their respective industries. The majority of them are based on exports and have demonstrated exceptional growth rates as well as sales records. It is through them that universities, research institutes, venture capital, and international joint ventures are connected. In China, Korea, and Malaysia, this type of incubation, which is based on the intersection of support tools, is already in operation ( $\mathrm{Li}, 2013)$. Some of these incubators are currently working to establish Incubator Nets, which are networks of incubators that are located in the same region, country, or have a similar focus to their own. Dot.com incubators showcase a model with distinguishing characteristics (Shepard, 2017). It is a relatively new but well-known portent in advanced markets, particularly the United States, that dot-com incubators or Internet business accelerators, which were formed as part of the "wave" of the new economy, were formed. They are distinguished by their strong project capital positioning as well as the shorter incubation periods that they have implemented (a few months instead of 2-3 years). Business incubators are a type of environment that is specifically designed for the formation of new businesses.

\section{Business Incubation in Pakistan}

In Pakistan, the concept of business incubation is still in its early stages. A business incubation centre was established in Lahore in 2006, which was the country's first such facility. There are approximately sixteen business incubators in Pakistan at the moment, six of which are women- 
focused and solely dedicated to the advancement of women-owned businesses (Shahzad et al., 2012). In Pakistan, the economic development of women has largely gone unnoticed. The Small and Medium Enterprise Development Authority (SMEDA) of Pakistan was the first to bring the concept of business incubators (BIs) to the country's attention (Shahzad, 2015). Some universities are also exploring the concept of university-based incubation centres, which is still in its early stages. For example, the Faisalabad Incubation Center (TFIC) at the University of Agriculture Faisalabad and the Business Incubation Center (BIC) at the Government College University Faisalabad (GCUF) are both actively engaged in their respective fields of endeavour. Many other entrepreneurship-oriented business schools are also planning to establish centres like this to help startups and fledgling companies accelerate their successful development by providing them with a variety of targeted resources and services.

Selection and graduation procedures are in place for Pakistani BIs, just as they are for their counterparts in other countries. The incubate company will be graduated once it has met all of the requirements listed below. Incubation can last up to 18 months in the case of one of the tenants. If the project has not been completed by that time, an extension of 2-6 months may be granted for it. Tenants have met all of the objectives outlined in the business plan. This indicates that the company has either licenced its technology to a third party or devised an exit strategy that will allow it to continue operating outside of the incubator with the least amount of disruption possible. If a tenant company fails to meet the quarterly targets twice in a calendar year, the space requirement of the tenant company exceeds the capacity of the incubator space. Consider the scenario in which the review committee determines that the project is no longer viable for whatever reason. This means that the landlord will be held liable if incubate fails to comply with its obligations under the lease agreement.

\section{Methodology}

Similar to Ali, Sheikh, and Latif (2021), the study follows a two-step approach. In the first phase of the study a cross-sectional survey of 100 tenants was conducted with the help of a structured questionnaire (Hong \& Lu, 2016) and in the second phase in-depth interviews of key stakeholders of BIs in Pakistan were conducted to triangulate the findings of the cross-sectional survey and to gain insights and suggestions from the stakeholders.

\section{Phase 1: Cross-sectional Survey}

During the phase one of this study the data were collected via a standardized questionnaire. The exact number of operating incubators in Pakistan was unknown at the time of the study, although 17 could be reached. Of the 17, 14 contactable incubators agreed to take part in the survey. The questionnaire was then mailed to 112 clients of the 14 participating BIs. After follow up, 100 questionnaires were submitted. The final response rate of $89 \%$ was deemed satisfactory as it was higher than the typical response rate of mail surveys (Alreck, Alreck, Settle, \& Robert, 1995). We analyzed different categories of business incubation services often given by business incubators in Pakistan (Qureshi, Hassan, \& Mian, 2021). Perceptions of the importance and effectiveness of these services were investigated using a five point Likert scale, similar to prior studies in the context of Pakistan (Ali, Aslam, \& Hafeez, 2021; Riaz, Shahid, \& Ali, 2021).

\section{Phase 2: In-Depth Interviews}

We conducted in-depth interviews with twelve respondents including managers of BIs operating in different universities of Pakistan, and other key stakeholders of BIs' activities, in the second round, to fins their perspectives and insights about the future of business incubation in Pakistan. The respondents were selected based on their experience with business incubation process. We made certain that we only interviewed respondents who had first-hand experience of dealing with business incubation. 
Interviews were done in informal settings to ensure that respondents gave their opinions freely and without hesitation (Ali \& Brandl, 2018). The interviews were tape-recorded and later transcribed and translated into English (as many respondents shared their views in Urdu and Punjabi). To encapsulate the future of business incubation in Pakistan themes were produced using open coding of interview transcripts.

\section{Results and Analysis: Phase 1}

Because the purpose of this study is to evaluate the effectiveness of BIs, if the facilities/services are effectively provided and the tenants believe that they are effectively provided, the tenants will be satisfied. We are attempting to determine the level of tenant satisfaction in this section of the study because there is a direct relationship between effectiveness and tenant satisfaction. It follows that if the effectiveness is high, the satisfaction will be high, and vice versa.

\section{Satisfaction from Infrastructural Facilities}

The satisfaction level of tenants with infrastructural faculties is shown in Table 1. The mean difference, calculated using the formula (importance-effectiveness=satisfaction), represents the tenants' satisfaction. The mean difference is positive at 0.359 , indicating that perceived importance is greater than perceived effectiveness, implying that tenants are less satisfied. The difference between the two measures is slightly greater, indicating that they believed infrastructure was critical to running a successful business but that the BIs did not deliver on that promise. The significance of the data is determined in the final column of the table, and the level of significance is set to five points; the result indicates that the data is significant because the value.002 is less than five points.

Table 1: Tenants' Satisfaction from Infrastructural Facilities

Paired Samples T-Test (Infrastructural Facilities)

\begin{tabular}{|c|c|c|c|c|c|c|c|c|c|}
\hline & & \multicolumn{5}{|c|}{ Paired Differences } & \multirow[t]{3}{*}{$\mathrm{t}$} & \multirow[t]{3}{*}{ Df } & \multirow{3}{*}{$\begin{array}{l}\text { Sig. } \\
\text { tailed) }\end{array}$} \\
\hline & & \multirow[t]{2}{*}{ Mean } & \multirow[t]{2}{*}{$\begin{array}{l}\text { Std. } \\
\text { Deviation }\end{array}$} & \multirow[t]{2}{*}{$\begin{array}{l}\text { Std. } \\
\text { Error } \\
\text { Mean }\end{array}$} & \multicolumn{2}{|c|}{$\begin{array}{l}95 \% \text { Confidence } \\
\text { Interval of the } \\
\text { Difference }\end{array}$} & & & \\
\hline & & & & & Lower & Upper & & & \\
\hline $\begin{array}{l}\text { Pair } \\
1\end{array}$ & $\begin{array}{l}\text { Infrastructural } \\
\text { Facilities } \\
\text { (Importance) } \\
\text { Infrastructural } \\
\text { Facilities } \\
\text { (Effectiveness) }\end{array}$ & 0.359 & 0.609 & 0.104 & 0.146 & 0.571 & 3.437 & 33 & 0.002 \\
\hline
\end{tabular}

\section{Satisfaction from Marketing Services}

Tenants placed a lower premium on marketing services than the other four groups. The first column of the following table calculates the difference between two means. The significance of marketing services - the effectiveness of marketing services - equates to tenant satisfaction with marketing services. The mean difference is positive, indicating that tenants place a premium on marketing services but are not receiving them effectively. The mean difference is 0.345 , which is slightly less than the mean difference for infrastructural facilities. This indicates that tenants are less satisfied with marketing services, but more satisfied with infrastructural facilities.

Satisfaction with physical infrastructure $>$ Satisfaction with marketing services $(0.359>0.345)$ 
The final column of the table also assesses the data's significance. Because the result 0.099 is less than the set point 5 , the data is statistically significant.

Table 2: Tenants' Satisfaction from Marketing Services

\begin{tabular}{|c|c|c|c|c|c|c|c|c|c|}
\hline \multicolumn{10}{|c|}{ Paired Samples T-Test (Marketing Services) } \\
\hline & & \multicolumn{5}{|c|}{ Paired Differences } & \multirow[t]{3}{*}{$\mathrm{t}$} & \multirow[t]{3}{*}{ Df } & \multirow{3}{*}{$\begin{array}{l}\text { Sig. } \\
\text { (2-tailed) }\end{array}$} \\
\hline & & \multirow[t]{2}{*}{ Mean } & \multirow[t]{2}{*}{$\begin{array}{l}\text { Std. } \\
\text { Deviation }\end{array}$} & \multirow[t]{2}{*}{$\begin{array}{l}\text { Std. Error } \\
\text { Mean }\end{array}$} & $\begin{array}{l}95 \% \\
\text { Interval } \\
\text { Difference }\end{array}$ & $\begin{array}{l}\text { Confidence } \\
\text { of the }\end{array}$ & & & \\
\hline & & & & & Lower & Upper & & & \\
\hline $\begin{array}{l}\text { Pair } \\
1\end{array}$ & $\begin{array}{l}\text { Marketing } \\
\text { Services } \\
\text { (Importance) } \\
\text { Marketing } \\
\text { Services } \\
\text { (Effectiveness) }\end{array}$ & 0.35 & 1.18 & 0.203 & -0.068 & 0.759 & 1.700 & 33 & 0.099 \\
\hline
\end{tabular}

\section{Satisfaction from Training Programs}

Tenants are dissatisfied with training programs despite their importance. Tenants placed a higher premium on training programs than the other four groups, but the mean difference is greater than the difference between the previous two groups' infrastructural facilities and marketing services. The mean difference is 0.576 , which is an unusually large value. This means that while training programs are critical, their effectiveness pales in comparison to their importance. Consider the distinctions between these three groups:

Satisfaction with Training Programs > Satisfaction with Physical Infrastructure > Satisfaction with Marketing Services (0.576>0.359>0.345)

Additionally, the data is statistically significant because the calculated value of 0.002 is less than the set point value of 5 .

Table 3: Tenants' Satisfaction from Training Programs

Paired Samples T-Test (Training Programs)

\begin{tabular}{|c|c|c|c|c|c|c|c|c|c|}
\hline & & \multicolumn{5}{|c|}{ Paired Differences } & \multirow[t]{3}{*}{$\mathrm{t}$} & \multirow[t]{3}{*}{ Df } & \multirow{3}{*}{$\begin{array}{l}\text { Sig. } \\
\text { (2-tailed) }\end{array}$} \\
\hline & & \multirow[t]{2}{*}{ Mean } & \multirow[t]{2}{*}{$\begin{array}{l}\text { Std. } \\
\text { Deviation }\end{array}$} & \multirow[t]{2}{*}{$\begin{array}{l}\text { Std. Error } \\
\text { Mean }\end{array}$} & $\begin{array}{l}95 \% \\
\text { Interval } \\
\text { Differen }\end{array}$ & $\begin{array}{l}\text { Confidence } \\
\text { of the } \\
\text { e }\end{array}$ & & & \\
\hline & & & & & Lower & Upper & & & \\
\hline $\begin{array}{l}\text { Pair } \\
1\end{array}$ & $\begin{array}{l}\text { Training } \\
\text { Programs } \\
\text { (Importance) } \\
\text { Training } \\
\text { Programs } \\
\text { (Effectiveness) }\end{array}$ & 0.576 & 1.00 & 0.171 & 0.227 & 0.925 & 3.356 & 33 & 0.002 \\
\hline
\end{tabular}

\section{Satisfaction from Networking Facilities}

The fourth category of facilities is networking. Not only is this fourth in the grouping, but also fourth in importance according to the tenants. The data are statistically significant because the 
calculated value of 0.001 is less than the specified value of 5 . The mean difference between the importance of networking and the effectiveness of networking facilities is the second most significant value in the table. The value is the greatest of the three groups previously discussed. The value is 0.715 , indicating that there is a significant disparity between significance and effectiveness. The following table compares four groups:

Satisfaction with networking> Satisfaction with training programs $>$ Satisfaction with infrastructure $>$ Customer satisfaction with marketing services $(0.715>0.576>0.359>0.345)$

Table 4: Tenants' Satisfaction from Networking Facilities

\section{Paired Samples T-Test (Networking)}

\begin{tabular}{|c|c|c|c|c|c|c|c|c|c|}
\hline & & \multicolumn{5}{|c|}{ Paired Differences } & \multirow[t]{3}{*}{$\mathrm{t}$} & \multirow[t]{3}{*}{$\mathrm{df}$} & \multirow{3}{*}{$\begin{array}{l}\text { Sig. } \\
\text { (2-tailed) }\end{array}$} \\
\hline & & \multirow[t]{2}{*}{ Mean } & \multirow[t]{2}{*}{$\begin{array}{l}\text { Std. } \\
\text { Deviation }\end{array}$} & \multirow[t]{2}{*}{$\begin{array}{l}\text { Std. Error } \\
\text { Mean }\end{array}$} & $\begin{array}{l}95 \% \\
\text { Interval } \\
\text { Difference }\end{array}$ & $\begin{array}{l}\text { Confidence } \\
\text { of the } \\
\text { e }\end{array}$ & & & \\
\hline & & & & & Lower & Upper & & & \\
\hline $\begin{array}{l}\text { Pair } \\
1\end{array}$ & $\begin{array}{l}\text { Networking } \\
\text { (Importance) } \\
\text { Networking } \\
\text { (Effectiveness) }\end{array}$ & $\begin{array}{r}0.715 \\
-\quad\end{array}$ & 1.14 & 0.196 & 0.316 & 1.11 & 3.650 & 33 & 0.001 \\
\hline
\end{tabular}

\section{Satisfaction from Consultancy Services}

A consultancy service is placed as fifth group in the questionnaire but the tenants also placed it at fifth position in the satisfaction. The mean difference of importance of consultancy services and effectiveness of consultancy services is the highest in the groups of five and very neat to 1 . The mean difference is 0.827 which is very high. The data is statistically significant as the calculated value is less than set point 5 . The value is 0.000 . The equation below provides the comparison of all five groups:

Consultancy Services Customer Satisfaction >

Satisfaction with networking $>$ Satisfaction with training programs $>$ Satisfaction with infrastructure facilities $>$ Satisfaction with marketing services

Table 5: Tenants' Satisfaction from Consultancy Services

\begin{tabular}{|c|c|c|c|c|c|c|c|c|c|}
\hline \multicolumn{10}{|c|}{ Paired Samples T-Test (Consultancy services) } \\
\hline & & \multicolumn{5}{|c|}{ Paired Differences } & \multirow[t]{3}{*}{$\mathrm{T}$} & \multirow[t]{3}{*}{$\mathrm{df}$} & \multirow{3}{*}{$\begin{array}{l}\text { Sig. } \\
\text { (2-tailed) }\end{array}$} \\
\hline & & \multirow[t]{2}{*}{ Mean } & \multirow[t]{2}{*}{$\begin{array}{l}\text { Std. } \\
\text { Deviation }\end{array}$} & \multirow[t]{2}{*}{$\begin{array}{l}\text { Std. Error } \\
\text { Mean }\end{array}$} & $\begin{array}{l}95 \% \\
\text { Interval } \\
\text { Difference }\end{array}$ & $\begin{array}{l}\text { Confidence } \\
\text { of the }\end{array}$ & & & \\
\hline & & & & & Lower & Upper & & & \\
\hline $\begin{array}{l}\text { Pair } \\
1\end{array}$ & $\begin{array}{l}\text { Consultancy } \\
\text { services } \\
\text { (Importance) } \\
\text { Consultancy } \\
\text { Services } \\
\text { (Effectiveness) }\end{array}$ & 0.827 & 0.988 & 0.169 & 0.482 & 1.170 & 4.881 & 33 & 0.000 \\
\hline
\end{tabular}

Results and Analysis: Phase 2

As shown in Table 6, various tenants and BI center managers were interviewed in depth. Pakistan 
has few BIs that are almost all government-owned. The government should expand the number of centers because people show a positive attitude towards BIs. More business incubation centers means more opportunities for young entrepreneurs. The government should help the private sector and universities. A large number of incubation centers are required to support the economy and provide business facilities. The government cannot start them all. The fact that educated people are running businesses is a good sign for the country. The university is the best place to provide this vital opportunity to initiate their own ventures.

There should be a check and balance on the active centers' work. Incubation depends on checks and balances. The authorities should not let the centers run free and should keep a close eye on their operations. The effectiveness of the provided facilities should be evaluated. How can the center know where they are lacking and what needs to be improved if they are not analyzing the effectiveness of the provided facilities?

It should be evaluated how many tenants come to the center and how many leave. The evaluation process can show the centers' performance better. BIs should attract people who want to start a business and have a plan. If people do not know about BIs and how they work, management should educate them by holding seminars and visiting universities. Because BIs are unknown, nationwide marketing and advertising is required.

Table 6: Categories of Interview Responses

\begin{tabular}{|c|c|c|}
\hline Category & Sample Response & Respondent \\
\hline State of the art & $\begin{array}{l}\text { "BI's purpose is not just to provide some infrastructural facilities like } \\
\text { building and prime location as almost every BIs is providing, it is also } \\
\text { necessary to give some attention to some other facilities like meeting } \\
\text { rooms, cafeteria and internet connection." }\end{array}$ & $\mathrm{R}-11, \mathrm{AT}$ \\
\hline Identity issues & $\begin{array}{l}\text { "Tenants conduct business in the BIs just as they would in the shell. There } \\
\text { is very little interaction with the outside world. For example, if a business } \\
\text { owner wishes for potential customers to learn about it, he must place a } \\
\text { business name sign to attract attention and inform people that he has the } \\
\text { item or service that they may require. However, tenants are not permitted } \\
\text { to place that sign outside the provided building. The management must } \\
\text { conduct an investigation into this matter." }\end{array}$ & R-3, AT \\
\hline $\begin{array}{l}\text { Development } \\
\text { issues }\end{array}$ & $\begin{array}{l}\text { "There are some training programs available on a general basis, but very } \\
\text { few on a customized basis. Every business faces different difficulties and } \\
\text { challenges, so BI should provide tailored training to each tenant based on } \\
\text { these challenges." }\end{array}$ & $\mathrm{R}-1, \mathrm{AM}$ \\
\hline $\begin{array}{l}\text { Professional } \\
\text { assistance }\end{array}$ & $\begin{array}{l}\text { "BIs should provide access to and instruction in the use of current } \\
\text { accounting applications." } \\
\text { "The management of BIs should train their employees on a regular basis } \\
\text { in modern management techniques so that they can better provide services } \\
\text { and facilities." }\end{array}$ & $\begin{array}{l}\mathrm{R}-5, \mathrm{AM} \\
\mathrm{R}-2, \mathrm{AM}\end{array}$ \\
\hline Behavioral side & $\begin{array}{l}\text { "Managers need to know their tenants well and be approachable and } \\
\text { proactive when dealing with them." }\end{array}$ & $\mathrm{R}-7, \mathrm{AM}$ \\
\hline Eco-system & $\begin{array}{l}\text { "BIs should work with other players in an ecosystem rather than playing } \\
\text { alone; in this way they will be better able in filling the gap between } \\
\text { perceived importance and perceived effectiveness." }\end{array}$ & $\mathrm{R}-9, \mathrm{AM}$ \\
\hline $\begin{array}{l}\text { Isomorphism, } \\
\text { Benchmarking }\end{array}$ & $\begin{array}{l}\text { Some BIs are unable to play an effective role because they copy what is } \\
\text { successful elsewhere; however, it is possible that what is successful } \\
\text { elsewhere is not suitable for you; therefore, each BI should tailor its policy } \\
\text { to its own market and tenants' needs. }\end{array}$ & $\mathrm{R}-4, \mathrm{AM}$ \\
\hline $\begin{array}{l}\text { Availability, } \\
\text { opportunity }\end{array}$ & $\begin{array}{l}\text { "In Pakistan, there are only a few BIs, all of which are almost entirely } \\
\text { government-run. Because there is a positive attitude toward these centers, } \\
\text { the government should increase the number of centers. More business } \\
\text { incubators mean more opportunities for entrepreneurs to start their own } \\
\text { businesses." }\end{array}$ & $\mathrm{R}-12, \mathrm{AT}$ \\
\hline
\end{tabular}




\begin{tabular}{ll}
\hline University BIs & "University-based business incubators can be very effective in stimulating R-8, AM \\
& young business graduates to start new ventures, which is a good sign for \\
the country that educated people are running businesses. The young and \\
educated are always eager to try new things and take risks in order to \\
succeed; the university is the best place to give them this crucial \\
opportunity to start their own businesses."
\end{tabular}

Source: Authors' own classification

$\mathrm{R}=$ Respondent, $\mathrm{AT}=$ Anonymous Tenant, $\mathrm{AM}=$ Anonymous Manager (BI Center)

\section{Analysis of Results and Future Outlook}

The role of BIs in fostering entrepreneurial activity cannot be overstated (Khorsheed, Al-Fawzan, \& Al-Hargan, 2014). There is a mismatch between the perceived importance and the actual effectiveness of BIs in providing services to their facilities. BIs purpose is not just to provide some infrastructural facilities like building and prime location as almost every BIs is providing. There was a growing sense of dissatisfaction among tenants due to the lack of modern facilities like internet facilities, which are essential for connecting with the outside world in today's globalized economy.

Tenants are doing business in the BIs like in the shell. The interaction with the outside world is very limited. For example, if you want potential customers to know about your business, you should put up some sort of business name sign to draw attention to it and inform passersby that you provide the product or service they seek. Although this name board may be placed outside of the provided building, tenants are prohibited from doing so. There are a few generic training courses available, but the number of tailored courses is much smaller. Every business face different kind of difficulties and challenges, so according to these challenges BI should provide customized trainings to every tenant (Peters, Rice, \& Sundararajan, 2004). BIs should provide training and facility of using modern accounting software. BIs management team must be aware of market needs and every team member know his character in incubation process.

BIs management should also provide training to their staff on periodical basis about the modern management techniques; they will be better able to provide facilities and services (Schwartz \& Hornych, 2008). Managers need to know their tenants well and be approachable and proactive when dealing with them. BIs should work with other players in an ecosystem rather than playing alone; in this way they will be better able in filling the gap between perceived importance and perceived effectiveness. This may not be appropriate for you, so it is important that every BI tailors its policies in accordance with the needs of its own market and tenants rather than simply copying what other BIs are doing successfully (Gstraunthaler, 2010). There are very few BIs in Pakistan and most of them are government owned. Government should increase the number of centers because there is positive attitude towards these centers. More business incubators mean more opportunities to start up business.

Government should take some initiatives to indulge the private sector and universities. In order to support the economy by providing business facilities, the private sector must be enticed by incentives to establish more incubation centers, which is nearly impossible for the government to initiate across the country. University based business incubation centers can play very effective role to create new ventures by stimulating the young business graduates it will be healthy sign for the country that educated folks are running businesses. The university is the best place to give the young and educated the opportunity to start their own ventures and do something different. They are always eager to do something different (Guerrero, Urbano, \& Gajón, 2020).

The active centers should be subject to checks and balances to ensure that they are operating as intended. The success of incubation is depending upon the check and balance. The road to the failure of BIs will undoubtedly lead to the authorities letting the centers run free and not keeping 
a close eye on how they are working. Analysis should be conducted about the effectiveness of the provided facilities. If the center is not analyzing effectiveness of the provided facilities how they can come to know where they are lacking and what needs to improve to get better results. Evaluation should be conducted about how many tenants are coming to the center and how many departs with success or failure. Evaluation process can portrait a better picture about the performance of the centers (Shahzad et al., 2012). A BI's goal should be to draw in those who are eager to start their own business and already have a game plan in place. If the people don't know about the BIs and there working how they will took advantage of the working of BIs, the management should attract the people by carrying some seminars and by visiting universities to educate people. Because so few people are aware of BIs, they need to be promoted and advertised across the country.

\section{Conclusion}

The concept of business incubation is not as developed in Pakistan as it is in European countries, as a result, only a few business incubation centers operate in the country; the study's major limitation is the small sample size. Due to the fact that these centers are located throughout the country, it is extremely difficult to contact and approach all tenants associated with these incubators, as they are not always available in the center; in order to run the business, they must perform some work outside the center. In Pakistan, the response rate is low; people are hesitant to respond, which makes data collection difficult. The purpose of this study was to determine the effectiveness of incubators, tenant satisfaction, and the role of business incubators in the creation of new ventures in Pakistan. In this regard, the study focused exclusively on the BIs tenants and the stakeholders who have direct impact on the incubation process and the creation of new ventures.

It is impossible to overstate the importance of BIs in fostering entrepreneurial activity. However, there is a mismatch between the perceived importance of business intelligence and its actual effectiveness in providing services to its facilities. Through incubation programs, BIs nurture entrepreneurs and their ventures by providing a variety of facilities and services. Thus, these mechanisms contribute to Pakistani start-ups' success. Tenants view this as a highly effective method of conducting business with the assistance of BIs. Tenants are somewhat satisfied that BIs are contributing to the creation of new ventures and employment opportunities in a moderately effective manner and view the facilities and services provided by BIs as critical to operating their businesses successfully. However, there exist a void between perceived significance and perceived effectiveness. The study finds that tenants are most satisfied with the marketing services and least satisfied with consultancy services provided by BIs in Pakistan, according to results. While this difference is slightly greater than average, it does not mean that BIs in Pakistan have failed to accomplish their mission. In Pakistan, business incubation is still in its infancy, and there is always room for improvement. This study highlights how Pakistan's BIs could be improved.

The purpose of a BI is not simply to provide infrastructure such as a building and a prime location, as almost every BI does; it is also necessary to pay attention to some other facilities such as meeting rooms, cafeterias, and internet facilities. Tenants were more dissatisfied with the lack of these facilities, as almost every business requires modern facilities such as internet connectivity to connect to the outside world in this globalized era, and they need access to modern tools and techniques. The majority of potential young entrepreneurs and students in Pakistan are unaware of this. This study will reorient graduates' thinking toward starting their own businesses, creating their own employment, and enlighten them as to how to best utilize the services of BIs in the infancy stage of the business. 


\section{References}

Ali, Q., \& Brandl, J. (2018). How complex domination enables selection: Academic hiring conventions in a Pakistani university. European Journal of Cultural and Political Sociology, 5(1-2), 140-164.

Ali, Q., Aslam, M. N., \& Hafeez, S. (2021). Impact of Online Recruitment on Organizational Attractiveness: An Experimental Study in the Context of Pakistan. iRASD Journal of Management, 3(3), 318-328.

Ali, Q., Sheikh, M. F., \& Latif, B. (2021). How Much Does the Recruitment Channel Really Matter: Recruiters' and Applicants' Behaviors in the South Asian Context. Journal of Management and Research, 8(1), 1-22.

Alreck, P. L., Alreck, P. L., Settle, R. B., \& Robert, S. (1995). The survey research handbook: McGraw-Hill/Irwin.

Atherton, A., \& Hannon, P. D. (2006). Localised strategies for supporting incubation: Strategies arising from a case of rural enterprise development. Journal of Small Business and Enterprise Development, 13(1), 48-61.

Bhabra-Remedios, R., \& Cornelius, B. (2003). Cracks in the egg: improving performance measures in business incubator research. Paper presented at the 16th Annual Conference of Small Enterprise Association of Australia and New Zealand, University of Ballarat, September-October.

Bruneel, J., Ratinho, T., Clarysse, B., \& Groen, A. (2012). The Evolution of Business Incubators: Comparing demand and supply of business incubation services across different incubator generations. Technovation, 32(2), 110-121.

Commission, E. (2002). Benchmarking of business incubators. Center for Strategy and Evaluation Services. European Commission Enterprise Directorate General. Brussels: European Commission, Center for Strategy and Evaluation Services.

Gstraunthaler, T. (2010). The business of business incubators: An institutional analysis-evidence from Lithuania. Baltic Journal of Management, 5(3), 397-421.

Guerrero, M., Urbano, D., \& Gajón, E. (2020). Entrepreneurial university ecosystems and graduates' career patterns: do entrepreneurship education programmes and university business incubators matter? Journal of Management Development, 39(5), 753-775.

Hackett, S. M., \& Dilts, D. M. (2004). A systematic review of business incubation research. The Journal of Technology Transfer, 29(1): 55-82.

Hamdani, D. (2006). Conceptualizing and measuring business incubation. Science, Innovation and Electronic Information Division, Statistics Canada.

Hassan, N. A. 2020. University business incubators as a tool for accelerating entrepreneurship: theoretical perspective. Review of Economics and Political Science. Vol. ahead-of-print No. ahead-of-print. https://doi.org/10.1108/REPS-10-2019-0142

Hong, J., \& Lu, J. (2016). Assessing the effectiveness of business incubators in fostering SMEs: evidence from China. International Journal of Entrepreneurship and Innovation Management, 20(1-2), 45-60.

Hyder, S., \& Lussier, R. N. (2016). Why businesses succeed or fail: a study on small businesses in Pakistan. Journal of Entrepreneurship in Emerging Economies, 8 (1), 82-100.

Incubation, U. B. (2003). The UKBI Benchmarking Framework for Business Incubation. UKBI, Birmingham.

Khorsheed, M. S., Al-Fawzan, M. A., \& Al-Hargan, A. (2014). Promoting technoentrepreneurship through incubation: An overview at BADIR program for technology incubators. Innovation, 16(2), 238-249.

Li, L. (2013). The path to Made-in-China: How this was done and future prospects. International Journal of Production Economics, 146(1), 4-13.

Lu, Y., Wu, J., Peng, J., \& Lu, L. (2020). The perceived impact of the Covid-19 epidemic: evidence from a sample of 4807 SMEs in Sichuan Province, China. Environmental Hazards, 19(4), 323-340. 
Money, M. (1970). University-related research parks. Ind. Res: 62-64.

Peters, L., Rice, M., \& Sundararajan, M. (2004). The role of incubators in the entrepreneurial process. The Journal of Technology Transfer, 29(1), 83-91.

Qureshi, S., Hassan, S. Z., \& Mian, S. A. (2021). Business incubation and acceleration in Pakistan: an entrepreneurship ecosystem development approach Handbook of Research on Business and Technology Incubation and Acceleration: Edward Elgar Publishing.

Riaz, A., Shahid, M., \& Ali, Q. (2021). A Moderated Mediation Model of Empowering Leadership and Employees' Innovative Work Behavior. Journal of Management and Research, 8(2), $1-18$.

Rice, M. P., Matthews, J. B., \& Kilcrease, L. (1995). Growing new ventures, creating new jobs: Principles \& practices of successful business incubation: Quorum.

Schwartz, M., \& Hornych, C. (2008). Specialization as strategy for business incubators: An assessment of the Central German Multimedia Center. Technovation, 28(7), 436-449.

Shafi, M., Liu, J., \& Ren, W. (2020). Impact of COVID-19 pandemic on micro, small, and medium-sized Enterprises operating in Pakistan. Research in Globalization, 2, 100018.

Shahzad, K. (2015). Performance evaluation of an industrial cluster-based common facility centre (CFC) in Pakistan. Journal of Infrastructure Development, 7(1), 35-54.

Shahzad, K., Bajwa, S. U., Ali, Q., \& Zia, S. (2012). Role of incubation in women entrepreneurship development in Pakistan. Asian Journal of Business Management, 4(2), 200-208.

Shepard, J. M. (2017). When incubators evolve: new models to assist innovative entrepreneurs. International Journal of Entrepreneurship and Innovation Management, 21(1-2), 86-104.

Voisey, P., Gornall, L., Jones, P., \& Thomas, B. (2006). The measurement of success in a business incubation project. Journal of Small Business and Enterprise Development, 13(3), 454-468.

Yasin, N., Khansari, Z., \& Tirmizi, K. (2021). Exploring the challenges for entrepreneurship business incubator hubs in the United Arab Emirates. International Journal of Globalisation and Small Business, 12(2), 190-212. 